\title{
Continuous Assessment of Undergraduates as Predictor of Their Academic Performance in Educational Administration and Planning Course
}

\author{
Yinusa Akintoye Faremi ${ }^{1, *}$, Margaret Funke Faremi \\ ${ }^{1}$ Department of Educational Foundations and Management, University of Eswatini, Kwaluseni, Swaziland \\ ${ }^{2}$ Department of Educational Management, College of Education, Osun State University, Osogbo, Nigeria
}

Received June 28, 2020; Revised August 16, 2020; Accepted September 11, 2020

\section{Cite This Paper in the following Citation Styles}

(a): [1] Yinusa Akintoye. Faremi, Margaret Funke Faremi , "Continuous Assessment of Undergraduates as Predictor of Their Academic Performance in Educational Administration and Planning Course," Universal Journal of Educational Research, Vol. 8, No. 11, pp. 5212-5221, 2020. DOI: 10.13189/ujer.2020.081122.

(b): Yinusa Akintoye. Faremi, Margaret Funke Faremi (2020). Continuous Assessment of Undergraduates as Predictor of Their Academic Performance in Educational Administration and Planning Course. Universal Journal of Educational Research, 8(11), 5212-5221. DOI: 10.13189/ujer.2020.081122.

Copyright $(2020$ by authors, all rights reserved. Authors agree that this article remains permanently open access under the terms of the Creative Commons Attribution License 4.0 International License

\begin{abstract}
The study was designed to investigate how Continuous Assessment (henceforth, CA) marks in Educational Administration and Planning course for undergraduate students will significantly predict their final examination marks. The study adopted ex post facto research design with a total of 221 undergraduates, who registered for a course in the second semester, at the Faculty of Education, Osun State University, Nigeria. The undergraduates' scores in continuous assessment and examination scores at the end of the semester formed the data for the study. The data collected were analysed using descriptive and inferential statistics. The results revealed that Biology students had the highest mean value when compared with the mean of undergraduates from other specialised areas. The regression analysis result $\left(\mathrm{F}_{1}\right.$, ${ }_{219}=40.414, \mathrm{p}<0.05$ ) reveals that the CA significantly predicts undergraduate students' performance in semester examination and made the best contribution to students' performance in Educational Administration and Planning. From the findings, it was concluded that continuous assessment scores are a good predictor of undergraduate students' performance in semester examination. It was recommended that there should be thorough supervision of the CA, all process must be monitored in Nigerian Universities for quality assurance.
\end{abstract}

Keywords Continuous Assessment, Final Exam, Educational Administration and Planning, Areas of
Specialisation

\section{Introduction}

Traditionally, before the introduction of Continuous Assessment (henceforth, CA) in Nigerian educational system, especially in institutions of higher learning, the assessment of students was based on the old method of assessment that was conducted at the end of completing the content of a course or programme, which is in the form of summative evaluation. This method of assessment failed to predict students' performance in completing the course or programme before the final examination. Alonge (2004) pointed out that the weekly, termly, quarterly and yearly report of students' performance provides a basis for predicting the students' achievement at the end of their programme or course. In Nigerian tertiary institutions, CA was recognised as a tool that was frequently used by lecturers and the school management in analysing students' performance (Shukla, 2019). The purpose of CA was pointed out by Shukla (2019) a way of enhancing students' learning, improving teachers'/lecturers' teaching skills and improving the assessment system of institutions. The introduction of CA into the educational system of any country improves the use of formative evaluation in which 
the three domains of education (Cognitive, Affective and Psychomotor) can be assessed, using a class test, assignment, experiment and project methods, instead of assessing only the cognitive domain (Patrick \& Uvietesivwi, 2018). In furtherance, the affective domain (interest, attitude, feeling, emotions) and the psychomotor domain of the students were ignored in the assessment process. The longstanding system had no outcome mechanism that reported on the student's area of weakness. More so, it gave scanty information to parents who did not depict the student's overall performance and this usually led to examination malpractice, as strong emphasis was laid on passing in order to be promoted to the next level.

The educational reform in Nigeria reviewed the educational policy of 1979 and 2004, in which case, the goals of the assessment were clearly stated in the new policy of 2013, in order to provide an accurate measure of students' abilities, enhance the global competitiveness of the products of the tertiary educational system, and improve the credibility of the examinations conducted in the schools. The 2013 policy encouraged educators at all levels of education to migrate to the Computer Based Test (CBT) assessment (Federal Republic of Nigeria, 2013). Most of the University general courses were assessed using CBT. The method of assessing learners of the 6-3-3-4 system of education was spelt out in the 1979 and 2004 educational policy. There was an improvement in the policy in 2013. Continuous Assessment was an innovation necessitated by reforms that were characterised by being diagnostic and guidance oriented, cumulative, comprehensive and capable of evaluating students using a variety of evaluation methods (Alonge, 2004). As explained by the National Open University of Nigeria (NOUN) (n.d), Educational Administration and Planning is a course to acquaint students with the important concepts in Educational Administration and Planning. Specifically, it focuses on the context in which administration is practised in schools, the organisation which forms the bedrock of any administrative practice, the types of organisations, principles of organisation, techniques in an organisation and organisational conflict, the chronological trends in the development of administration, stressing the theories in the areas of personnel management, bureaucracy, scientific management and human relations. In Osun State University, all undergraduate students are required to perform excellently in the course, Education Administration and Planning, for the certification of a degree in education. The course is studied in the third year at the university.

Based on observation, Educational Administration and Planning course is compulsory for all undergraduate students at the Faculty of Education, Osun State University and other universities in Nigeria, taught at level three. Evaluation of the academic performance of undergraduate courses (educational management inclusive) by the National University Commission (NUC) provides two types of evaluation. The continuous assessment conducted within the semester that comprises the mid-semester test and assignment in form of take-home assessment and the final examination that is usually conducted after the course outline has been exhausted, at end of the semester examination, as specified by each university calendar and regulation. The continuous assessment constitutes 30-40 percent of the total final score for each course, while the final examination constitutes $60-70$ percent of the total final score, depending on the university regulation that guides the evaluation process (Ohuruogu \& Umahi, 2013, p. 220). The scores of the undergraduate students, used for this study, were categorised into 30 percent $\mathrm{CA}$ and 70 percent final semester examination.

Gender issues are ever so important that the world's paradigm changed even as we begin to re-evaluate human circumstances within the framework of the "21st Century". Gender equity means fair-mindedness of treatment for women and men, boys and girls, with respect to their needs. In education, this means the recognition by policymakers and educators of the inbuilt differences of both girls and boys, in terms of abilities and circumstances, and acting accordingly, in order to ensure that no one is left behind or disadvantaged (Kashu, 2014). The importance of examining performance concerning gender focused primarily on the socio-cultural differences of the girls and boys (Adigun, Onihunwa, Irunokhai, Sada \& Adesina, 2013).

\subsection{Conceptual Framework and Literature Review}

In literature, scholars and writers in Sociology, Psychology, educational sciences and their sub-disciplines have discussed factors affecting students' academic performance, and various theories have been suggested concerning these factors. Some scholars stressed more on individuals' internal characteristics (e.g. self-concept, intelligence, etc.) while some others considered as important the external characteristics (family, educational environment, social status etc.). On the other hand, one of the most important factors underlying development is education (Garkaza, Banimahd, \& Esmaeilic, 2011). This study was based on system theory. A system is a connection of interrelated parts that form a whole. The concept of system theory can be traced back to Aristotle in 384BC; he suggested that the whole is greater than the sum of its parts (Nwankwo, 1982). The system is "a set of things connected or interdependent to form a complex unity; a whole composed of parts on orderly arrangement according to some scheme of plan" (Christensen \& Basilgan, 2013 citing Koontz, O’Donnell \& Weihrich, 1980). It is also the collection of people, resources, concepts, and procedures intended to perform some identifiable functions or to serve a goal (Christensen \& Basilgan, 2013). It is noted from this aforementioned that all aspects of human lives are a system; be it a body, school, government agencies and businesses, in which case each of 
these has sub-systems. The system theory is relevant to Educational Management because the Educational system and the concepts of interaction and interdependence of parts with each other and with the wider system are applicable. With this description, this study is related to system theory because system theory in education explains how educational inputs are turned into outputs through the transformational process.

Based on the framework in figure 1, it can be deduced that inputs (students' time, materials, community resources, teachers' time and teachers' ability) create an avenue for transformational factors (continuous assessment inclusive) which invariably bring about the output (students' academic performance) that showed the picture of the impact of various inputs on the learner. This helps in achieving the overall goal of the educational system. Hence, the system theory showed how the various inputs put forward by the system bring about a change in the output, through the evaluation of various input factors on the learner. This further brings about desirable changes in the academic performance (positive or negative) of the learner, for the aim of achieving the overall goal of the system without bias, based on gender (male and female) of the learners.
A

INPUT

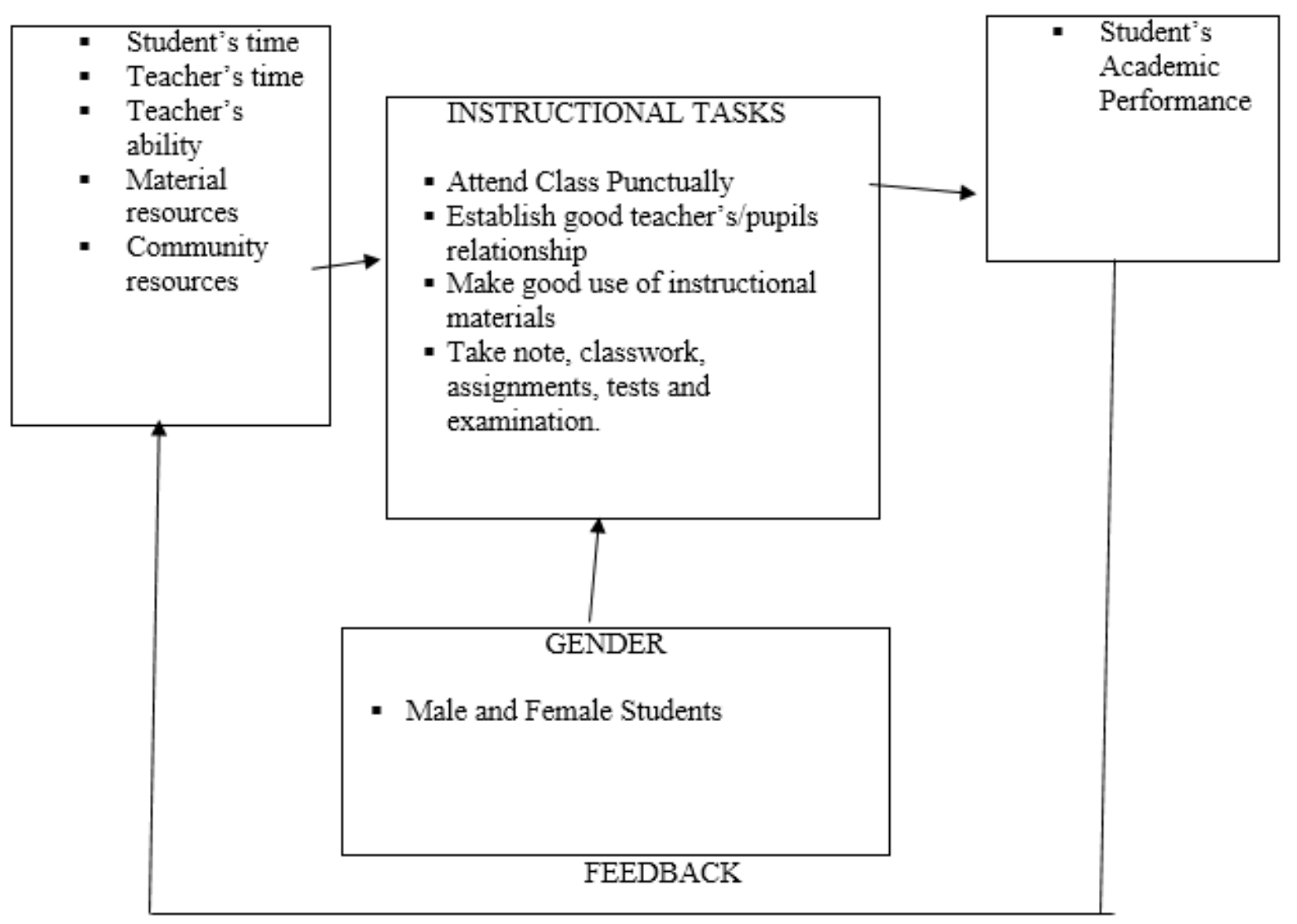

Figure 1. Conceptual model of continuous assessment of undergraduate stud as predictor of their academic performance in educational management course (Adapted from Faremi ${ }^{2}, 2012$ ) 
The term "assessment" is commonly used during the evaluation of students, both at the commencement stage and at the completion of the course. The outcome of the assessment is useful in making a decision and in providing information on the extent to which the students have benefitted in a particular course or subject. The duration of measuring the ability and worth of the students is the yardstick that the evaluators based their judgment on. In education, we need such information to determine the extent to which students have benefited from a course of study (Onihunwa, Adigun, Irunokhai, Sada, Jeje, Adeyemi \& Adesina, 2018). According to Turnbull and Hornby (2013), assessment means an appraisal or evaluation. It is also viewed as the action or an instance of making a judgment about something (Atondo, Abah \& Naakaa, 2019). Assessment can be defined as a process of collecting data that will be used to form a decision, in this case, about students' achievement. Students' assessment is as important as the teaching process itself (Iljazi, 2013). Assessment clarifies for students what is important, what counts, how they will spend their time and how they will see themselves as learners. If you want to amend student learning, then change the methods of assessment (Azzah, 2015).

However, Onihunwa et al. (2018) identified three distinct types of assessments, depending on when and why they are carried out: diagnostic, or initial, assessments; formative, or continuous, assessments; and summative, or final, assessments. Diagnostic, or initial assessments are intended to bring the starting point for training into line with students' prior knowledge and skills. This type of assessment is unnecessary in the case of courses forming a part of a given qualification or degree program, as such courses are scheduled within a curriculum that takes into account the skills and knowledge that students are expected to acquire each year (Onihunwa, et al., 2018).

By definition, Continuous Assessment is an assessment that is designed into the instructional process. It is helpful to take place during the instructional program; it can be said that continuous assessment constitutes formative evaluation (Erdoğan, 2012). According to the National Steering Committee on Continuous Assessment in Nigeria Schools, led by Professor Yoloye, continuous assessment is viewed as a method of determining what a child gains from schooling in terms of knowledge, industry and character development, taking into account all his/her performances in tests, assignments, projects and other educational activities during a given period, year, or during the entire period of an educational level (Adodo, 2013). Continuous Assessment is conducted in all schools, as a formative assessment to inform educators and learners about learners' progress to improve learning (Azzah, 2015). Continuous assessment is a holistic approach to learning in its entirety, and which begins with the decisions of teachers' performance on the first day of school \& ends with the decisions that the teachers and administrators make on learners regarding end-of-month/term/year grading \& promotion (Alausa, 2004 cited in Basome \& Allida, 2018)

Meanwhile, Academic achievement, according to Muhammad (2007) quoting Musa (2000), refers to the quality of outcomes produced by students as reflected in the quality of their examination scores (Muhammad, 2007). In furtherance, he stated that if more CA is given, it means more motivation on the part of the students and it is hoped that the achievement will increase. Continuous Assessment is repeatedly used to motivate students to learn. Students' academic performance has been a vital area of significance for higher education institutions. Evaluation of factors associated with academic performance of university students become a topic of growing interest in a higher educational circle (Shahzadi \& Zahoor, 2011). Also from observation, the question of students' academic performance is very essential in the sense that many factors, including the school, community etc. determine students' productivity. Al Shehry \& Awad Youssif, (2017) in AL-Mutairi (2010), opined that Cumulative Grade Point Average (CGPA), Grade Point Average (GPA) and their test results were considered by most researchers around the world to be an indicator of student performance, over a particular semester or an academic program

Onihunwa et al. (2018), citing Adebule (2004) observed that the differential scholastic achievement of students (educational management undergraduates inclusive) in a country like Nigeria has been a source of concern to the educators' parents and government. This is as a result of the benefits derived from education for national development (Onolemhenmhen \& Osunde, 2018). In Nigeria today, scholars agree that the standard of education is falling. Also, the government and parents have concluded that the money spent on education has not yielded an expected outcome. At various educational levels, the rate at which students fail at both external and internal exams is disgusting.

Getting quality education for the citizens of a country requires good preparation by the government and other stakeholders (Bocccanfuso, Moore, Whitney, 2010). Also, standardised achievement tests are useful in assessing the performance of students in a specific area. The outcome of any achievement test serves as a good indicator of previous learning and can be used as a predictor of any future achievement in education (Onihunwa, et. al., 2018).

Research conducted on continuous assessment and academic performance revealed that a large ratio of students passed CA but failed in the final exam and the course. No strong correlation was found between the CA marks and the final examination marks. Consequently, CA does not give practically the same pass/fail rates as the midterm and final exams (Azzah, 2015). Moreover, the scores obtained by students in CA is a good determinant of students' achievement in their final semester examination in the tertiary institutions (Onihunwa, et. al., 2018). Atondo, Abah and Naakaa (2019) also found that there was a strong relationship between the scores of Continuous Assessment and achievement of Students in Basic Certificate 
Examination Mathematics. It was concluded that continuous assessment had positive effects on students' achievement in primary schools (Samiullah \& Anjum, 2017). Thus, this study sought information on Continuous Assessment of undergraduates as predictors of their academic performance in educational management.

In the same vein, Research conducted on gender and academic performance revealed that there is no significant correlation between male and female performance in practical physics. This implies that the performance of any gender can in no way affect the performance of the other. It means one could not predict the performance of female students from male students or vice versa; they are independent of one another (Aina, 2013). Also, in relation to the mean scores of students in social studies, there was a slight effect of gender on the achievement of male and female students (Nnamani \& Oyibe, 2016). Kashu (2014) discovered that the overall performance across the subjects during the five years under study (2007-2011) was fair for both boys and girls, though boys did better in science subjects compared to girls who excelled in Home. The results of the study further showed that even though the male students had slightly better performance compared to the female students, it was not significant. Adesoji and Kenni (2013) posited that gender has a significant impact on the academic performance of chemistry students' in WASSCE; while in NECO, gender has no impact on students' performance in chemistry. Eze, Ezenwafor and Obi's (2015) study revealed a significant difference in students' academic achievement as a result of age and gender. This means that relationship exists between the academic achievement of the university VTE students and their age and gender in Nigeria universities. Goni, Yagana, Ali and Bularafa's (2015) study indicated that there were no significant differences between gender and academic performance in favour of female students. Hdii and Fagroud's (2018) study posited that girls proved to be more likely to perform better than boys in different subjects in Morocco. Meanwhile, Khwaileh and Ibrahim (2010) showed that female undergraduate students outperform male undergraduate students in their GPAs in Jordan. For Faremi $^{1}$, Akinwarere and Fakolujo's (2017) study, it was revealed that there is no significant difference between the performance of boys and girls in basic technology subject multiple-choice items. Conclusively, Attah and Ita's (2017) results showed that gender has no significant influence on academic performance among senior secondary school students.

Similarly, research on academic performance, based on areas of specialisation of undergraduates indicated that students from same areas of specialisation that is, from the same department, had good academic performance than their counterparts who were not from the same discipline (Oladebinu, Amos \& Oyediran, 2018). Also, department preference has negative effects on the academic achievement of students. On the other hand, there was a high degree of variation of academic achievement of students among departments while there was similarity within a department (Garkaza, Banimahd \& Esmaeilic,
2011). Conclusively, findings of Dike, Anyanwu, Zachariah, Dalhatu and Samuel (2018) showed that there was no significant difference between students' performance in three science subjects like Biology, Chemistry, Physics and their science overall performance in the period allocated to study.

\subsection{Statement of the Problem}

The evaluation procedure of undergraduate students in each course offered in a semester involves the conduct of continuous assessment (CA) on or before the mid-semester and final examination at the end of the semester, in which every undergraduate student puts in his/her best during an assessment to perform better. There is a belief that students that did well in continuous assessment should be able to perform in semester examination better since CA is a significant part of the final score. It may work as expected if the semester examination and the CA followed the same process. It is also a belief that there must be a correlation between the mark obtained in the CA and exam mark. With these, there is a need to investigate if $\mathrm{CA}$ marks will significantly predict undergraduate students' performance in semester examination at the end of a semester.

\subsection{Purpose of the Study}

The study was designed to find how Continuous Assessment (CA) marks in Educational Administration and Planning of undergraduates will significantly predict their final examination marks. It was also designed with a view that the CA can serve a better chance when there is a problem with an examination mark at the end of the semester.

\subsection{Objectives of the Study}

The objectives of the study are to:

1. Find out if there is a difference in the final examination scores of undergraduate students that took the Educational Administration and Planning course from different areas of specialisation.

2. Establish the fact that $\mathrm{CA}$ will be able to predict undergraduate students' performance in semester examination scores in Educational Administration and Planning course.

3. Determine whether other factors such as areas of specialisation and gender, when combining with CA will significantly influence undergraduate students' performance in semester examination scores in Educational Administration and Planning course.

4. Determine if there is a difference in the performance of male and female undergraduates in CA, semester examination and their total examination scores at the end of the semester in Educational Administration and Planning. 
5. Examine if there is a difference in the performance of undergraduate students in the final examination scores based on areas of specialisation.

\subsection{Research Question}

Is there any difference in the final examination scores of undergraduate students from different areas of specialisation in Educational Administration and Planning course?

\subsection{Research Hypotheses}

1. Continuous assessment scores of undergraduate students will not significantly predict their performance in semester examination in Educational Administration and Planning course.

2. The combination of continuous assessment, gender, and areas of specialisation of undergraduates will not significantly predict their performance in semester examination in Educational Administration and Planning course.

3. There is no significant difference between the performance of male and female undergraduate students in Educational Administration and Planning course in:
i. Continuous assessment
ii. Semester examination
iii. Final examination scores obtained in the course

4. There is no significant difference among the performance of undergraduate students in final examination scores in Educational Administration and Planning course based on their areas of specialisation.

\section{Methodology}

Ex post facto research design was adopted for this study. This design was defined by Sharma (2019) as "that research, in which the independent variable(s) have already occurred and in which the researchers start with the observation of a dependent variable(s)". It is also referred to what is done afterwards whereby the independent variable is not manipulated because its manifestation has already occurred. The study is a quantitative comparative study. The total number of 221 undergraduate students who registered for Educational Administration and planning (EDU 308) course in 2018/2019 academic year at Faculty of Education, Osun State University, Nigeria were used for the study. The continuous assessment scores weighted 30 percent, semester examination scores weighted 70 percent and the final examination scores weighted 100 percent by adding the CA scores with semester examination scores (30 $+70=100$ ). The three sets of scores were collected through the kind approval of the Head of Department of Educational Management of the University for analysis. The data collected were coded using a six-point coding system which ranges from 1 to 6 and entered into SPSS package in order to find out the predictive power of the continuous assessment on examination scores. No questionnaire was used as additional sources of information. The data collected were analysed using descriptive and inferential statistics. The mean and standard deviation of the scores of undergraduate students were determined through SPSS. Regression Analysis and $\mathrm{t}$-test were also carried out through the same process. The results obtained were tabulated for discussion.

\section{Results}

\subsection{Research Question}

Is there any difference in the final examination scores of undergraduate students from different areas of specialisation in Educational Administration and Planning course?

Table 1. Showing the mean and standard deviation of performance of undergraduate students from different areas of specialisation.

\begin{tabular}{|c|c|c|c|}
\hline Department & $\mathrm{N}$ & Mean $\bar{X}$ & SD \\
\hline Economics & 40 & 3.8500 & 1.4420 \\
\hline $\begin{array}{c}\text { Educational } \\
\text { management }\end{array}$ & 28 & 4.500 & 1.3194 \\
\hline English & 58 & 3.7414 & 1.3962 \\
\hline $\begin{array}{c}\text { Guidance and } \\
\text { Counselling }\end{array}$ & 23 & 3.5217 & 1.7286 \\
\hline Political science & 44 & 3.4318 & 1.5158 \\
\hline Biology & 13 & 4.6154 & 1.3868 \\
\hline Chemistry & 7 & 4.2857 & 0.7559 \\
\hline Mathematics & 4 & 3.7500 & 0.9574 \\
\hline $\begin{array}{c}\text { Physical Health } \\
\text { Education }\end{array}$ & 4 & 3.7500 & 0.5000 \\
\hline Total & 221 & 3.8416 & 1.4545 \\
\hline
\end{tabular}

Table 1 showed the performance of undergraduate students from different areas of specialisation. Biology students (4.6154) had the highest mean value, followed by Educational management, Chemistry and Economics with a mean value of $4.5000,4.2457$ and 3.8500 respectively. Mathematics, and Physical and Health Education had the same mean value of 3.7500 that shows that undergraduate students in the two departments had the same knowledge in education management. English had a mean value of 3.7414, while Political science had the least mean value of 3.4318. This implied that there a slight difference in students' academic performance based on areas of specialization.

\subsection{Research Hypotheses}

Hypothesis One: Continuous assessment scores of undergraduates will not significantly predict their performance in semester examination in Educational Administration and Planning course. 
Table 2. Result of Regression Analysis of CA predictive power

\begin{tabular}{|c|c|c|c|c|c|c|c|c|}
\hline Model & Sum of Square & Df & Mean Square & F & Sig & R & $\mathrm{R}^{2}$ & ${\text { Adjusted } \mathrm{R}^{2}}$ \\
\hline Regression & 97.478 & 1 & 97.478 & 40.414 & 0.000 & 0.395 & 0.156 & 0.152 \\
\hline Residual & 528.223 & 219 & 2.412 & & & & & \\
\hline Total & 625.701 & 220 & & & & & & \\
\hline
\end{tabular}

a. Dependent Variable: Exam

Table 3. Result of Regression Analysis on the combination of CA, gender and areas of specialisation predictive power

\begin{tabular}{|c|c|c|c|c|c|c|c|c|}
\hline Model & Sum of Square & Df & Mean Square & F & Sig & R & $\mathrm{R}^{2}$ & ${\text { Adjusted } \mathrm{R}^{2}}$ \\
\hline Regression & 100.238 & 3 & 33.413 & 13.798 & 0.000 & 0.4 & 0.16 & 0.149 \\
\hline Residual & 528.463 & 217 & 2.421 & & & & & \\
\hline Total & 625.701 & 220 & & & & & & \\
\hline
\end{tabular}

a. Dependent Variable: Exam

Table 4. Contribution of Gender, Areas of Specialisation and CA to semester examination scores in Educational Administration and Planning course.

\begin{tabular}{|c|c|c|c|c|c|}
\hline Model & \multicolumn{2}{|c|}{ Unstandard Coefficient } & \multicolumn{3}{c|}{ Standard } \\
\hline Model & B & Std. Error & Beta & $\mathrm{t}$ & Sig. \\
\hline Constant & 0.543 & 0.553 & & 0.982 & 0.327 \\
\hline Gender & 0.224 & 0.211 & 0.066 & 1.064 & 0.289 \\
\hline Areas of specialization & 0.001 & 0.055 & 0.002 & .025 & 0.98 \\
\hline CA & 0.719 & 0.115 & 0.391 & 6.267 & 0.000 \\
\hline
\end{tabular}

Table 2 showed the value of the $\mathrm{R}$ square coefficient of determination $\left(\mathrm{R}^{2}=.156\right)$ indicates that the predictor variable $\mathrm{CA}$ accounted for $15.6 \%$ of the total variance in the performance of undergraduates in semester examination in Educational Administration and Planning course, while the remaining $84.4 \%$ unexplained variation is largely due to other variables not included in the study that can account for the performance of undergraduates in semester Educational Administration and Planning examination. The regression result $\left(\mathrm{F}_{1,219}=40.414, \mathrm{p}<0.05\right)$ in the table reveals that CA significantly predicts undergraduate students' performance in the semester final examination.

Hypothesis two: The combination of continuous assessment, gender, and areas of specialisation of undergraduate students will not significantly predict their performance in semester examination in Educational Administration and Planning course.

The value of the $\mathrm{R}$ square coefficient of determination $\left(\mathrm{R}^{2}=.160\right)$ indicates that the combination of the predictor variables jointly accounted for $16 \%$ of the total variance in performance of undergraduate students in Educational Administration and Planning course while the remaining $84 \%$ unexplained variation is largely due to other variables not included in the study, and which can account for the performance of undergraduate students in Educational Administration and Planning course. The regression result
$\left(\mathrm{F}_{3,217}=13.798, \mathrm{p}<0.05\right)$, The combination of $\mathrm{CA}$, gender and the areas of specialisation of undergraduate students significantly predict their performance in Educational Administration and Planning course in the final semester examination.

Table 4 showed the regression result, the table revealed that the single best predictor of undergraduate students' performance in semester examination scores in Educational Administration and Planning course is continuous assessment (CA) $(\mathrm{t}=6.267, \mathrm{p}<.05, \beta=.391)$, which also made the most contribution to semester examination scores. This was closely followed by gender $(\mathrm{t}=1.064, \mathrm{p}>.05, \beta=.066)$ and areas of specialisation $(\mathrm{t}=.025, \mathrm{p}>.05, \beta=.002)$. The gender and areas of specialisation contributed poorly to the students' semester examination scores in Educational Administration and Planning course and not significant. This implies that the $\mathrm{CA}$ is the best predictor variable that can significantly predict undergraduate students' performance in semester examination.

Hypothesis three: There is no significant difference between the performance of male and female undergraduate students in Educational Administration and Planning course in:

- Continuous assessment

- Semester examination

- $\quad$ Final scores obtained in the course 
Table 5. t-test showing the difference between the performance of male and female undergraduate students

\begin{tabular}{|c|c|c|c|c|c|c|c|}
\hline EDM Scores & Variable & $\mathrm{N}$ & $\bar{X}$ & $\mathrm{SD}$ & $\mathrm{Df}$ & $\mathrm{t}$ & sig \\
\hline CA & Male & 101 & 3.4554 & 0.9851 & 219 & -0.762 & 0.447 \\
\hline & Female & 120 & 3.55 & 0.8585 & & & \\
\hline Semester Exam & Male & 101 & 3.257 & 1.7243 & 219 & -1.287 & 0.2 \\
\hline & Female & 120 & 3.55 & 1.6492 & & & \\
\hline Total Scores & Male & 101 & 3.7228 & 1.5108 & 219 & -1.115 & 0.266 \\
\hline & Female & 120 & 3.9417 & 1.4041 & & & \\
\hline
\end{tabular}

Table 6. ANOVA that showing the difference in the performance of undergraduate students

\begin{tabular}{|c|c|c|c|c|c|}
\hline Model & Sum of Square & Df & Mean Square & F & Sig \\
\hline Between groups & 31.696 & 8 & 3.962 & 1.936 & 0.056 \\
\hline Within groups & 433.761 & 212 & 2.046 & & \\
\hline Total & 465.457 & 220 & & & \\
\hline
\end{tabular}

Table 5 revealed that the female undergraduate students had the highest mean value in CA, semester examination and total scores in the course. But there was no significant difference between the performance of male and female in $\mathrm{CA}$, semester exam and their final total scores in Educational Administration and Planning course.

Hypothesis four: There is no significant difference among the performance of undergraduate students in Educational Administration and Planning course based on their areas of specialisation.

Table 6 showed that there was no significant difference between the performance of Undergraduate students in the final examination in Educational Administration and Planning course from different areas of specialisation $\left(\mathrm{F}_{(8,212)}=1.936, \mathrm{p}>.05\right)$.

\section{Discussion of Findings}

As anticipated, the results of the study revealed that undergraduate students studying Biology in Educational Administration and Planning course had the highest mean value when compared with undergraduate students who specialised in Educational Management, Chemistry Economics, Mathematics, Physical and Health Education, English and Political Science. The implication of this is that those students studying biology emerge as the best students in Educational Administration and Planning course in the academic year which is a compulsory semester course and which undergraduate students from the faculty of education must offer before graduating from the university. Oladebinu, Amos \& Oyediran (2018) found that students from same department or area of specialisation had better academic performance than their counterparts who were not from the same department, which support the findings of this study.

The continuous assessment scores in Educational Administration and Planning course significantly predicts the performance of undergraduate students in the semester examination. The findings corroborated Samiullah and
Anjum (2017) who concluded that continuous assessment had positive effects on students' achievement in primary schools. In the same vein, Onihunwa, et al. (2018) revealed that the final grades of students are shown to be a function of the scores obtained in the C.A. On the contrary, the findings negate Azzah (2015) who discovered that no strong correlation was found between the CA marks and the final examination marks.

The combination of CA, gender and the discipline of the undergraduate students significantly predicted their performance in Educational Administration and Planning course in the final semester examination. It was revealed that CA was the best predictor that significantly contributes to the students' performance in the semester examination while gender and area of discipline have no predictive power and had a very low contribution to undergraduate students' final examination scores in Educational Administration and Planning course. This finding disagreed with that of Adesoji and Kenni (2013) who posited that gender has a significant influence on students' academic performance in chemistry.

The findings on academic performance of male and female undergraduate students revealed that there was no significant difference between the performance of male and female students in the CA, semester exam and their total scores in Educational Administration and Planning course as a faculty course which disagreed with the findings of Eze, Ezenwafor and Obi (2015), which revealed a significant difference in students' academic achievement as a result of gender. On the other hand, the study conformed to the findings of Aina (2013) who discovered that the performance of any of the genders can in no way affect the performance of the other.

The finding also showed that there was no significant difference between the performance of Undergraduate students in the final examination in Educational Administration and Planning course from different areas of specialisation which corroborate the findings of Dike et al. (2018), reports which showed that there was no significant difference between students' performance in three science 
subjects like Biology, Chemistry, Physics and their science overall performance in the period allocated to study.

\section{Conclusions}

Based on the findings, undergraduate students studying Biology education had the highest mean value and they performed better than undergraduate students from other disciplines in Educational Administration and Planning course. The continuous assessment scores in the course significantly predicted the performance of undergraduate students in semester examination and contributed positively to their academic performance in Educational Administration and Planning as a faculty course. The performance of male and female students in CA, semester examination and total scores showed no difference in Educational Administration and Planning course.

\section{Recommendations}

Based on the finding, it is thus recommended that:

1. There must be thorough supervision of continuous assessment (CA); all processes must be monitored in Nigerian Universities for quality assurance.

2. Students whose performance fall below $40 \%$ in CA should not be given the privilege to write the final examinations in Educational Administration and Planning.

3. The management, lecturers who serve as supervisors and invigilators should ensure strict compliance with examination ethics during the administration of the continuous assessment.

4. Lecturers should ensure that each unit of the course outline where the students are to be examined should be completed on or before the commencement of the test. This is also applicable to assignment-based CA.

\section{REFERENCES}

[1] Adesoji F. \& Kenni A. (2013). Continuous assessment, mock results and gender as predictors of academic performance of chemistry students in WASSCE and NECO examinations in Ekiti State. Journal of International Education Studies; 6(7).

[2] Adigun J., Onihunwa, J., Irunokhai, E., Sada, Y. \& Adesina, O.(2013). Effect of gender on students' academic performance in computer studies in secondary schools in New Bussa, Borgu Local Government of Niger State. Journal of Education and Practice, 6 (33), .Retrieved from https://www.iiste.org.

[3] Adodo, S. (2013). Quality assurance, relevance and institutionalization of continuous assessment implementation as perceived by lecturers and students in Nigeria. Journal of education and social research, MCSER publishing, Rome- Italy, 3(3): 253-260. Retrieved from https://www.semantic scholar.org/2b21/b567f08c593997e2d4d78182e262d261efa 3.

[4] Ali, I. \& Abdalla, M. (2017). Educational management, educational administration and educational leadership: definitions and general concepts. Journal of Medicine (SASJM), 3(12):326-329. Retrieved from http://sassociety.c om/sasjm.

[5] Alonge, M. F. (2004). Measurement and evaluation in education and psychology. Ado Ekiti: Adebayo Printing Limited.

[6] Aina, J. K. (2013). Gender analysis of students' academic performance in physics practical in colleges of education, Nigeria. Journal of Science and Education Development Institute. 3 (5). Retrieved from http://www.ejournal.sedinst. com.

[7] Al Shehry, A. \& Awad Youssif, S. M. (2017). Factors affecting academic performance of undergraduate students at Najran preparatory year for girls-Najran university 2015-2016. International Journal of Asian Social Science, 7(1), 1-18.

[8] Attah, R. \& Ita, P. (2017). Gender as predictor of academic achievement in English among senior secondary school two students in Calabar metropolis, Cross River State. Global Journal of Educational Research. 16: 149-153. http://dx.doi.org/10.4314/gjedr.v16i2.9.

[9] Atondo, G., Abah, J. \& Naakaa, T. (2019). Continuous assessment as a predictor of students achievement in mathematics at the junior secondary school level in Makurdi Local Government Area of Benue State, Nigeria. World Wide Journal of Multidisciplinary Research and Development. 5(2), 18-29. Retrieved fromhttps://www.wwj mrd.com.

[10] Azzah A. (2015). Comparison between continuous assessment and final examination scores. Quality Management \& Enhancement in Higher Education. Conference proceedings, Muscat, 24-25.

[11] Basome S. \& Allida, V. (2018) The influence of continuous assessment on academic performance in primary schools of Ibulanku sub-county, Iganga district (Uganda). Baraton Interdisciplinary Research Journal, 8(Special Issue), 1-7.

[12] Bocccanfuso, C., Moore, K., Whitney, C.(2010). The way to promote educational achievement and attainment beyond the classroom. Child trends. Retrieve from https://www.childtrends.org/wp-content/uploads/2013/03/C hild_Trends_2010_07_07-Ed_Achievement.

[13] Christensen, B. \& Basilgan, M. (2013). Economic behaviour, game theory and technology in emerging markets. A volume in the advances in finance, accounting and economics (AFAE) Book series. Business science reference.

[14] Dike, N. I., Anyanwu, R., Zachariah B., Dalhatu H. \& Samuel F. (2018) Academic performances in biology, chemistry and physics of male and female students in a Nigerian tertiary institution. Journal of Education and Practice, 9(20). Retrieved from https://www.iiste.org.

[15] Erdoğan, T. (2012). Research results on portfolio assessment: implications for teachers considering its promises and challenges. Conference proceedings. 
Hacettepe University, Ankara. Retrieved from https://www.researchgate.net/publication/327231273.

[16] Eze, T. I., Ezenwafor, J. I. \& Obi, M. N. (2015) Effects of age and gender on academic achievement of Vocational and Technical Education (VTE) students of a Nigerian University. Journal of Emerging Trends in Educational Research and Policy Studies, JETERAPS, 6(1): 96-101. Retrieved from https://www. jeteraps.scholarlinkresearch.c om.

[17] Federal Republic of Nigeria (2013). National policy on education ( $6^{\text {th }}$ ed.), Lagos: NERDC

[18] Faremi, M. F. (2012). Instructional supervision and primary schools teachers' productivity in South West Nigeria. Unpolished Ph.D Thesis, Ekiti State University, Ado-Ekiti, Nigeria.

[19] Faremi, Y. A., Akinwarere, K. C., \& Fakolujo, A. B. (2017). Mental ability of junior secondary school students in basic technology multiple choice objective test in Nigeria. European Journal of Educational Science (EJES), 4(2), $107-120$

[20] Garkaza, M. Banimahd, B. \& Esmaeilic, H. (2011). Factors Affecting Accounting Students' Performance: The Case of Students at The Islamic Azad University. Procedia - Social and Behavioral Sciences, International Conference on Education and Educational Psychology (ICEEPSY 2011), $29 ; 122-128$.

[21] Goni, U., Yagana W., Ali K., \& Bularafa, M.(2015). Gender difference in students' academic performance in colleges of education in Borno State, Nigeria: Implications for counselling. Journal of Education and Practice. 6(32): 107114. Retrieved from https:// www.iiste.org.

[22] Hdii, S. \& Fagroud, M. (2018). The Effect of Gender on University Students' School Performance: The Case of the National School of Agriculture in Meknes, Morocco. KULTUTRA IR VISUOMENE். Socialiniu tyrimu žurnalas. 9 (1). https://dx.doi.org/10.7220/2335-8777.9.1.4.

[23] Iljazi, T. (2013). Continuous assessment develops thinking skills, quality of learning and teaching. Conference Proceedings, National Academy of Science review. 61-68.

[24] Kashu, J. N. (2014). Survey on gender and academic performance in secondary schools in Kenya. Unpublished Masters' thesis, University of Nairobi.

[25] Khwaileh, F., \& Ibrahim, H. (2010). Gender differences in academic performance among undergraduates at the University of Jordan: Are they real or stereotyping? College student Journal. 633-648. Retrieved from https://www.rese archgate.net/publication/ 280655919.

[26] Koontz, O., \& Weihrich (1980). Management ( $7^{\text {th }}$ ed.). New Prentice Hall: Eaglewood Cliff N.J.

[27] Larkin, T.L (2014). The student conference: A Model of authentic assessment. IJEP, 4 (2).http://dx.doi.org/10.3991/ ijep.v4i2.3445.

[28] Muhammad, B. A. (2007). Effects of continuous assessment on academic achievement of NCE chemistry students in Kaduna state. An Unpublished Master thesis, Ahmadu Bello University, Zaria.

[29] National Open University of Nigeria (n.d). Concept and theories of educational administration and planning (EDA811) school of Education, NOUN, Nigeria.

Nnamani, S. C. \&. Oyibe, O. A. (2016). Gender and academic achievement of secondary school students in social studies in Abakaliki urban area of Ebonyi State. British Journal of Education, 4(8), 72-83. Retrieved from https://www.eajournals.org.

[30] Nwankwo, J. I. (1982). A guide to effective supervision of instruction in Nigerian schools. Enugu: Fourth Dimension Publishers.

[31] Oduntan, F. (2018). The use of continuous assessment in tertiary institutions. A Paper Presented on A-One Day Workshop for Academic Staff of Ajayi Crowther University. Oyo.

[32] Oladebinu T. O., Amos A. A. \& Oyediran, W. O. (2018). Affecting Students' Academic Performance in Colleges of Education In Southwest, Nigeria. British Journal of Education 6(10), 43-56. Retrieved from https://www.eajour nals.org.

[33] Ohuruogu, C. \& Umahi, O. (2013). Nigerian legal methods. Newcastle: Cambridge Scholars. Retrieved from https://www. books.google.com/books.

[34] Onihunwa, J., Adigun, O. Irunokhai, E., Sada, Y., Jeje, A., Adeyemi, O \& Adesina, O. (2018). Roles of Continuous Assessment Scores in Determining the Academic Performance of Computer Science Students in Federal College of Wildlife Management. American Journal of Engineering Research (AJER), 7(5) 7-21. Retrieved from https://www. ajer.org.

[35] Patrick, U. O. \& Uvietesivwi, O. A. (2018). Assessment of teachers' implementation of continuous assessment in senior secondary schools in Delta Central Senatorial District Advances in Social Sciences Research Journal, 5(7) 316-342. https//doi:10.14738/assrj. 57.4466.

[36] Samiullah, M. \& Anjum, A. (2017). Effect of continuous assessment techniques on students' performance at elementary level. Bulletin of Education and Research, 39(1), 91-100.

[37] Shahzadi, E. \& Zahoor, A. (2011). A study on academic performance of university students. Proc. 8th International Conference on Recent Advances in Statistics Lahore, Pakistan. 255-268.

[38] Sharma, S. (2019). Experimental and ex post facto designs. https://www.researchgate.net/publication/ 333220493 Experimental_and_Ex_Post_Facto_Designs.

[39] Shukla, A. (2019). Continuous assessment features and purpose. www.toppr.com/bytes/continuous-assessment features-and-purpose/

[40] Tesfaw, D. \& Derebew, M. (2014). Multilevel analysis on determinants of academic achievement of second year regular students: the case of Addis Ababa university school of commerce. Journal of Research \& Method in Education (IOSR-JRME). 4(6) Ver. IV, 42-4. https://doi/10.9790/7388 $-04644249$.

[41] Turnbull, J. \& Hornby, A. S. (2013). Oxford advanced learners dictionary of current English ( $8^{\text {th }} \mathrm{ed}$.). London: Oxford University Press. 